\title{
Trade-offs, Compromise and Democratization in a Post-authoritarian Setting
}

\author{
Paul James Carnegie ${ }^{1}$ \\ ${ }^{1}$ Department of International Studies, American University of Sharjah, Sharjah, United Arab Emirates \\ Correspondence: Paul James Carnegie, Department of International Studies, American University of Sharjah, \\ University City, Sharjah 26666, United Arab Emirates. Tel: 971-6-515-4703. E-mail: pcarnegie@aus.edu
}

Received: June 17, 2012 Accepted: July 5, 2012 Online Published: October 18, 2012

doi:10.5539/ass.v8n13p71 URL: http://dx.doi.org/10.5539/ass.v8n13p71

\begin{abstract}
Reconstituting the disarticulated political space of authoritarian breakdown is anything but straightforward. Distinct trade-offs and ambiguous outcomes are all too familiar. This is in no small part because political change involves compromise with an authoritarian past. The very fact of this transition dynamic leaves us with more questions than answers about the process of democratization. In particular, it is important to ask how we go about interpreting ambiguity in the study of democratization. The following article argues that the way we frame democratization is struggling to come to terms with the ambiguity of contemporary political change. Taking Indonesia as an example, the article maps a tension between authoritarianism and subsequent democratization. The story here is not merely one of opening, breakthrough, and consolidation but also (re-)negotiation. There is also an unfolding at the interstices of culture and politics and of that between discourse and practice. Unfortunately, the insight gained will not lessen some of the more undesirable aspects of Indonesia's post-authoritarian outcome but it does afford us a more fine-grained reading of the reconfigured patterns of politics that are emerging. It may even generate discussion on how we interpret democratization and its dynamics of change.
\end{abstract}

Keywords: ambiguity, contextual narratives, democratization, Indonesia, political space, re-negotiation

\section{Introduction}

It is all too easy to assume that when a country undergoes a transition from authoritarian rule it is inextricably moving towards democracy. This is a false assumption. Since the high water mark of the 'Third Wave', experience tells us otherwise. It may be one thing to establish formal democratic institutions, but quite another to sustain them over time without stagnation or reversal. In recent years, we have certainly witnessed some unusual patterns of transformation with numerous scholars drawing our attention to the emergence of what are more commonly referred to as 'hybrid regimes'( Casper 1995; Diamond 1997, 2002: 21-36; McFaul 2002: 212-244; Ottoway 2003; Zakaria 1997: 22-43). Neither one thing nor the other, these types of regime outwardly display some of the formal procedural features of 'democracy' but they 'play' by considerably different 'rules'. From Azerbaijan and Turkmenistan in the Caspian Sea Basin to Cambodia in Southeast Asia and Nigeria in West Africa, a major feature of this current 'wave' of democratization is ambiguity.

This seems to rest on the fact that during democratization the preferences and capacities of actors reflect past developmental patterns and underlying societal conventions. Often times it is their own perceived self-interests or those of 'reserved domains' that end up playing significant roles in shaping events. Whilst not wanting to sound too pessimistic, this reality can constrain even the best of intentions. It certainly introduces a high level of contingency into our understandings of democratization. Yet, what it does indicate clearly is the unpredictable and discontinuous character of democratization.

This article brings the above considerations into focus through one case in particular, namely Indonesia. We are now well over a decade since the archipelago's initial transition and its fortunes in the intervening years afford us an opportunity to study ambiguity at work. Indonesia continues to not only reorganize but transform and regenerate. If we are to unravel this process, identifying the manner in which political actors draw upon and reinvent traditional identifications is an important step. The following article maps some of the contingent contours of this journey through the key contextual narratives of nationalism, decolonization and patrimonial authority. Of course, the shape Indonesian democratization is neither limited to nor conditioned in exclusivity by 
these readily recognizable aspects of Indonesian history but relating their narrative threads to the process does provide a basis from which to trace a pattern of political compromise and ambiguity.

\section{Disjunctive Dynamics}

If we are to take democratization's disjunctive dynamics seriously, we have to recognize that the process is far more ambiguous than a linear explanation predicated on direct casual factors presumes. In fact, trade-offs and unusual patterns of transformation are at the very heart of the process. We are dealing with something far beyond the rational capacity of political actors to bargain about clear-cut choices. As the evidence of our current wave of 'democratizers' highlight the legacies of authoritarian rule remain present even as the old institutional structures unravel. Distinct trade-offs and ambiguous outcomes arise in no small part because change involves a compromise with this authoritarian past (Bermeo 1990: 359-377; Karl 1990: 1-23). There is little doubt that reconstituting the disarticulated political space of authoritarian breakdown is as going to be as difficult to explain, as it is to put into practice. The story that needs telling is not merely one of opening, breakthrough, and consolidation but of (re-)negotiation between culture and politics and of that between discourse and practice. This understanding is indebted to the insights of the work of Benedict Anderson (1991) who drew attention to the fact that people who perceive themselves as part of a political community ultimately imagine it. The nation is, therefore, a social construct that rests upon a process of invention and re-invention of traditions. In these terms, contextual narratives are the constitutive substance of perception and provide symbolic resources to political actors from which they can legitimate a post-authoritarian grammar of political action. After all, it is human actors shaping change in particular settings. Nonetheless, they have to turn structural factors into effective political resources of change in order to do so (Kim, Liddle and Said 2006: 247-268). The dynamics of which involve political actors drawing selectively upon symbolic narratives (the power of which is not necessarily tangible in the physical sense) to construct a grammar of legitimacy for their actions. One that sets in motion specific interpretations and interpellations that appeal to mass audiences accustomed to viewing things through distinctive lenses. Paradoxically, the selective utilization of both material and discursive strategies and practices is the enactor of a process it simultaneously constrains. In other words, in a complex interplay structure shapes agency as agency transforms structure into resources for change. The compromised character of a post-authoritarian settlement is in large part a product of the tension generated between structure and agency as the following will illustrate.

\section{Indonesian Nationalism}

A brief glance at Indonesia's geography and demographics tells us that any form of nationalism there will be a complex phenomenon. As the world's largest archipelago nation, it is host to vast diversity. There is five main islands - Java, Sumatra, Sulawesi, Kalimantan (60 percent of Borneo), and Papua (western half of New Guinea) but also 17,000 other smaller islands/islets with approximately 922 of these inhabited permanently. Major ethnic populations include Javanese (41.7 percent), Sundanese (15.4 percent), Malay (3.45 percent), Madurese (3.4 percent), Batak (3 percent), Minangkabau (2.7 percent), and Betawi (2.5 percent). Add in the fact that there are approximately 360 ethno-tribal groupings, 25 language groups, and over 250 dialects, and it is fairly clear that the establishing a state capable of holding this diverse conglomeration of peoples together is no mean feat. Not just in terms of state building capacity but in the construction a suitably wide yet integrative national identity. Fortunately, a shared history of anti-colonial struggle, the introduction of a shared national language (bahasa Indonesia) and a comprehensive state education system have all played a role in establishing a strong sense of national political identity.

\subsection{Nation Building, Ideology and Powerful Myths}

To elaborate, prior to full independence and at a time when the Dutch were trying to regain control over parts of the archipelago, there was an attempt to isolate Republican forces through a federal solution. Governor General Van Mook's efforts to revive the prewar plans of the Visman Commission, however, met with forceful opposition and ultimately floundered. Indonesian independence leaders like Sukarno, Hatta, and Sjahrir mobilized popular support around the idea of a single territorial unit of rule and a collective destiny. To encapsulate their struggle, these independence leaders deployed the term perasaan senasib sepenanggungan (the feeling of common fate and plight) and cast the Dutch as oppressors. This symbolically powerful discourse gave the diverse peoples of the archipelago a narrative through which to recognize themselves as a community under colonial oppression and imagine something different (Siegel, 1997). They rejected Dutch economic interests, language, institutional symbols, and practices (Bertrand 2004: 28-29). Ironically, during the years of living dangerously, Suharto would end up jailing novelist Pramoedya Ananta Toer and banned his semi-fictional paean to Indonesian nationalism, the Buru Quartet. 


\subsubsection{Pancasila and Socialization}

Repressive practices aside for a moment, Sukarno sought to unite Indonesia's different cultures behind the common purpose of nation building. In terms of national identity, Pancasila (panca - five; sila - principle) would play an instrumental role in unifying the fledgling republic. Initially, the Investigating Committee for the Preparation for Independence (BKI - Badan Penyeliduk Usaha Persiapan Kemerdekan Indonesia) helped formulate this new national ideology, later enshrined in Article 29, Section 1, of the 1945 Constitution. Pancasila as the official ideology of the republic linked national identity to five guiding principles - belief in one God, compassionate humanity, the unity of Indonesia, consensus democracy, and social justice. The purpose was to allow for recognition of diversity in Indonesian society while at the same time appealing to the greatest possible number of Indonesians. In combination with Sukarno's presidential charisma and power, it formed "a powerful myth of nationhood" (Mulder 1998: 121). It also had similarities with Supomo's idea of negara integralistik (an integrated state) put forward in 1945 (Simanjuntak 1994). The new national ideology became a potent political symbol for mobilizing the population and transcending societal cleavages. The interrelated principles of bhinneka tunggal ika (unity in diversity) loosely reflected and resonated with traditional Javanese values and traditions. This infused the national political project with symbolic markers, including musyawarah (deliberation), mufakat (consensus), kekeluargaan (family), manunggaling kawula (unity of the ruler and ruled), and gotong royong (mutual cooperation). All of which inculcated in the collective consciousness of the populace an image of a community that chooses a wise ruler by mutual consent. This heavy reliance on Javanese symbolism and cultural values did not always sit easily with other parts of the archipelago. In fact, Sukarno judiciously adopted the Malay of the islands as the common national language (bahasa Indonesia) to deflect claims of pro-Javanese bias that were all too obvious.

\subsubsection{Suharto and the Rise of the New Order}

After the fall of Sukarno (1965-1966) and the brutal purge of at least 500,000 alleged communist sympathizers, Suharto shifted Pancasila's common platform of unity into a full-fledged justification for his rule (Cribb 1990). He selectively re-invented Pancasila for development purposes by re-deploying its vague principles as a legitimating grammar for his authoritarian practices. Rather than a national aspiration, in Suharto's hands it became a culturally symbolic affirmation for his brand of modernizing authoritarian corporatism. There was nothing short of a systematic attempt to de-contest societal identity vis-à-vis the New Order (Orde Baru 1965-1998). What Suharto's authoritarian re-interpretation of Pancasila did was develop incrementally a hegemonic political discourse (bahasa pejabat) of New Order guidance. He promoted the idea of a "floating mass" (massa mengambang) populace to further consolidate his rule. Borrowing from Supomo's idea of manusia seutuhnya (whole man of humanity) and reinterpreting it as manusia seuthisuhnya pembangunam (total Indonesian) infused New Order rule with corporatist ideas about organic integrated wholeness.

Following New Order logic, a floating mass needed a paternal guide to steer them along the correct path. This symbolically infused assemblage tapped into and exploited cultural notions of obedience (budaya petunjuk) and further reinforced traditional high Javanese notions of the little people (wong cilik) as ignorant (masih bodoh). The logic being that their place was to remain servile (budak) and obedient (patuh) to their ruler (gusti) and subordinate to the dominant class (wong gede), in this case, the controllers of the state apparatus. In other words, by fusing the fetishized desire for modernization with ideas of traditional Javanese cosmology, Suharto went a long way to normalizing the New Order's brand of authoritarianism in the Indonesian imagination. Suharto utilized the state bureaucracy to reinforce this symbolic positioning of the New Order by rolling out various socialization techniques. Civil servants and community leaders followed programmes set up by the Agency for Pancasila Development (BP-7) and the Pancasila Promotional Programme (P-4). In addition, schools taught Pancasila moral education. These mechanisms of control in the distribution of cultural knowledge allowed Suharto to construct a strong narrative structure around his corporatist vision. In Gramscian terms, we have an ideological imbrication that prioritized state above politics (Hoare and Nowell Smith 1971: 51).

For Suharto, framing the New Order's legitimacy in these terms allowed him the excuse to justify repression, electoral intimidation, and control of the media in the name of national interest. Under the auspices of the New Order, Pancasila became a projection of what the ruling elite deemed important, something that gradually almost imperceptibly normalized and internalized their authority and rule in public discourse. Once accomplished it virtually paralyzed the capacity for self-organization among the populace and set the stage for the sweeping away of all forms of dissent by intimidation, repression and co-option. Between 1983 and 1985, Suharto banned any organization that failed to conform to Pancasila principles. Of course, there were some notable exceptions. The massive socio-religious Nahdlatul Ulama (NU - Awakening of Ulama) and Muhammadiyah were only tolerated on the condition that they did not agitate for political change. Other voices of dissent arose from time to 
time, but they usually gained little traction against New Order hegemony. In May 1980, for instance, public criticism of Suharto's moves to redefine Pancasila to mean "loyalty to the president" met with swift and ruthless retaliation. Suharto banned news coverage of the high-level officials who had signed the Petisi Limapuluh (the Petition of Fifty) and imposed travel restrictions on them whilst rescinding their lucrative government contracts. It is not hard to appreciate how the internalization of this sort of intimidation and the fear of reprisal deterred potential dissent.

\section{Colonial Legacies, Centralized Patrimonial Authority and Qiao Sheng}

Having situated attempts to de-politicize Indonesian society within the context an evolving form of authoritarian rule, we can now turn to another significant configuration of the Sukarno and Suharto eras namely, patrimonial authority. The following genealogical reading gives us a slightly different but necessary perspective on these tendencies.

In the same way as Mahmood Mamdani (1996) highlighted that colonial rule left a lasting impression in the African context. Similarly, Benedict Anderson (2001) argues that the image of a 'state' in Indonesia was a nineteenth-century colonial construct of defined boundaries (Anderson 2001). Taking these claims at face value raises a paradox. Although nationalist leaders rejected all things colonial in the catharsis of the postcolonial moment, the patterns of authority and exploitation established under colonialism did not simply disappear post-independence. In fact, they seemed to reiterate in some very strange ways. The doubling of a reflective image, as if a feedback loop is reproducing a distorted facsimile of vaguely familiar power-relations.

To elaborate, in pre-independence Indonesia, the Dutch administrated the archipelago as a colonial possession geared primarily to extract revenues for their own self-serving interests. In a classic rule by proxy strategy, under the Dutch many local aristocracies gained a level of political power over state apparatus. For the Dutch, co-opting local powerbrokers and enforcers was the most pragmatic way of maintaining order and control. It created the operational mechanism through which to regulate local relations and at the same time kept the indigenous population trapped in an ethnically ordered system. The Dutch legacy left a reified patrimonial network of political elites who had acquired conditional political power as colonial proxies and a pressure cooker of simmering ethnic tensions. For instance, the Dutch had maintained a strategic divide between sino-Indonesians (qiao sheng) and native Indonesians (pribumi). They gave the former commercial and tax collection privileges, effectively utilizing them as an intermediary or comprador class in their commercial activities across the archipelago. This policy unwittingly or otherwise served to fuel pribumi distrust and animosity toward sino-Indonesians. Consequently, during the post-independence Sukarno era, the goal of building a strong pribumi business class meant that the Chinese suffered political and economic marginalization.

\subsection{Clientelism, Cronys and Cukong}

The situation remained largely the case in the Suharto era. But somewhat differently after 1965, prominent Chinese entrepreneurs who were select cronies of Suharto did enjoy extensive regime patronage. In a distorted reflection of past practices, patronage relationships formed between high-ranking state actors and sino-Indonesian entrepreneurs. Indonesian military men adopted the role as the "masters" of politics while financial backers (cukong) assumed their role as "masters" of capital (MacIntyre 2000: 248). In fact, the likes of Liem Sioe Liong (Sudono Salim) and The Kien Seng (Mohammad 'Bob' Hasan) became some of the richest men in Asia.

On the other hand, this cukong system of patronage did little to alleviate resentment towards sino-Indonesians. Your average sino-Indonesian continued to experience insidious discrimination under the New Order including exclusion from the military, a lack of political representation, forced urban relocation and coercive assimilation practices. Day-to-day deprivations saw the routine closure or nationalization of Chinese schools, the banning of Chinese literature, signs, and characters and pressure to marry into pribumi families, convert to Islam, and adopt Indonesian sounding names. The Indonesian state even introduced specially marked identity cards, and certain legal restrictions. The Dutch instrumentality of maintaining a strategic divide between qiao sheng and pribumi became no forgotten accident of the past. Even as the new nationalist leaders were zealously trying to distance themselves from all things Dutch, the imprinted patterns they left behind were marks more difficult to shift. The spreading of the psychological stain left history to play out in a most invidious manner.

\subsection{Patrimonial Political Economy}

The reason I call this a distorted reflection of the past is not to absolve the post-independence era or claim that history repeats, far from it. Shining a light on these contingent contours does afford us, however, glimpses of the present in terms of how things end up the way they do. The new patterns and practices that emerged in the 
immediate aftermath of independence were disconcertingly familiar. For instance, the new political elite in Jakarta often made deals with local aristocracies, most notably in Bali, to ensure popular support for the fledgling republic and nationalist project. Villagers would support local elites who in turn supported central elites in anticipation of reciprocal benefit. Under Suharto, this precipitated an intensive centralization of authority with local elites firmly attached by patronage networks to a hierarchical state power-base in Jakarta. Using a mixture of fear and rewards across the state bureaucracy, business, and the military Suharto was able to ensured support for his leadership. As Harold Crouch once noted, "the New Order bore a strong resemblance to the patrimonial model. Political competition among the elite did not involve policy, but power and the distribution of spoils." (Crouch 1979: 578)

Having said this, the viability and legitimacy of this form of rule also depended on credible economic growth and development. Initially, from 1969 onwards, the national five-year development programmes (REPELITA Rencana Pembangunan Lima Tahun) formed major planks of an economic interventionism. And by the late 1970s and 1980s the switch to export oriented industrialization helped modernize the country's infrastructure and transform its economic production base. Nevertheless, it was development hollowed out from within. Suharto's rule eventually descended into a form of 'sultanism' as power and resources became increasingly concentrated around his personalized rule. Suharto's control of an elaborate patronage machine that extended through Golkar across the archipelago ensured that virtually every important economic and political player, particularly the military, depended on some form of state patronage. At the same time, the rent-seeking behavior and financial base of Suharto's crony capitalism relied on resource revenues, especially those generated by Pertamina (the state-owned oil and gas monopoly). This worked for a time at least when oil and gas exports defined Indonesia's political economy and shielded it from market realities. By 1981, for example, oil and gas accounted for 82 percent of all exports and 73 percent of government tax revenue. Nevertheless, this reliance on state patronage and personal favours exchanged between state officials, business interests, and community elites was a boomerang in motion.

\subsubsection{Repressive Development and Decline}

To elaborate, Suharto sat at the apex of not just a political structure but also "a system akin to business franchising." (McLeod 2000: 101) This allowed him "to bestow privileges on selected firms, so he effectively awarded franchises to other government officials at lower levels to act in a similar manner."(McLeod 2000: 101) As a result, state actors had a hand in most aspects of economic activity. All of which led to a pattern of economic growth beset by patrimonial rent-seeking and economic inequality. Suharto's "repressive developmentalism" was simply too reliant on personal 'cronyism' and resource revenues to compete effectively in a globalizing economy. To put it bluntly, Suharto's regime policies and practices ill equipped it to match the burgeoning economies of South Korea and other 'Asian Tigers'. Throughout the 1980s, foreign investment fell due to restrictions on foreign investment and high subsidies given to state-owned companies. Richard Robison (1986: 105) neatly sums up the situation in Indonesia as an "entrenchment and centralization of authoritarian rule by the military, the appropriation of the state by its officials, and the exclusion of political parties from effective participation in the decision-making process." A situation that also brought about an incremental erosion of confidence in Indonesia's banking sector on world markets, especially when the regime lost all financial credibility in the wake of the 1997 Asian Financial Crisis, the latter being a major catalyst in Suharto's downfall in 1998.

\section{The Military, Golkar and Authoritarian Rule}

Of course, anatomizing Suharto's patrimonial corporatism would be incomplete without mention of his two main props namely, the Military and Golkar. The Indonesian National Defence Force (TNI - Tentara Nasional Indonesia formerly known as ABRI - Angkatan Bersenjata Tentara Republik Indonesia - Armed Forces of the Republic of Indonesia), for instance, played a key role in Suharto's patrimonial corporatism. Even by the standards of bureaucratic authoritarianism, the military occupied an unusual political and economic role in the regime matrix. A role that traces back to armed resistance against colonial rule that gave it a symbolic place in Indonesian iconography as the "guardian" of the Republic.

Its heavy involvement in the economic sector also traces back to the nationalization of Dutch colonial companies in the 1950s. In the Sukarno era, military involvement in the economy became accepted practice in order to raise extra-budgetary revenue for operations. Its position as protector of the Republic's integrity also led it into greater involvement in economic and social development (Crouch 1979). From 1958, a series of laws legitimized the military's dual function (dwifungsi) within the Indonesian Republic. First, Law No. 80/1958, and MPR Decree No. II/1960 (A/III/404/ Sub/C) consolidated the military's power by guaranteeing it a fixed representation in 
Majelis Permusyawaratan Rakyat (MPR -People's Consultative Assembly), Dewan Perwakilan Rakyat (DPR-House of Representatives), and local parliaments. This effectively established the military as a functional group of the state. Secondly, during the New Order era, Suharto further strengthened military influence across the political and economic landscape through Law No. 16/1969 and Law No. 5/1975. Laws that officially recognized the military's dual function. By the 1980s, the military's masuk desa programme even involved it in local development. Suharto also rewarded loyal military supporters with posts that offered the prospect of substantial material gain. Other officers entered into business under the tacit understanding that the regime would oblige with licenses, credit, or contracts.

As a central prop of the New Order, it is of little surprise that it retained significant influence in the post-Suharto era. Although the military is no longer as powerful politically as it once was, its extensive economic presence makes it impossible to ignore. Institutionalized resistance to rolling-back its economic involvement is strong because government funding only accounts for about 30 percent of its operating budget (Singh 2000: 184-216). Even with constitutional reform in 2002 and the formal removal of allocated seats in parliament in 2004, it is clear that the military remains very much involved in the economy. Military-owned businesses operate in most areas of domestic investment and they are involved in various joint ventures with foreign and Chinese partners. The fact that the military's territorial structure remains largely intact also ensures access to 'revenues' from fishing and logging to coffee production. The KODAM (regional military commands), KOREM (sub-regional military commands), and KODIM (district military commands) are all involved in 'self-funding' activity usually organized through a network of yayasan (foundations similar to NGOs), not to mention illegal levies, smuggling, and protection rackets (McCulloch 2003: 94-124).

\subsection{Golkar, Hegemony and Patronage}

On the operational side, Golkar was the other key player in Suharto's patrimonial corporatist matrix. Its prototype emerged during the Sukarno era in 1963 as the Joint Secretariat of Functional Groups. This ABRI led initiative allowed the military to mobilize support against Partai Komunis Indonesia (PKI -Indonesian Communist Party). In 1965, Suharto with the help of General Ali Murtopo turned the various groups of military officers, civil servants, technocrats, government officials, administrators, and educators into the political machinery of the New Order state. The "restructuring" of Indonesia's political party system also facilitated its dominant role. By 1971, Golkar, Partai Demokrasi Indonesia (PDI - Indonesian Democratic Party) and PPP, were the only three permitted state-licensed political parties. Golkar dominated the other two parties through distribution of patronage and allocation of resources combined with a virtual monopoly on communications and funding (MacIntyre 2000: 248-273). The elections of 3 July 1971 cemented Golkar's position in Indonesia's political firmament with 62.8 percent of the vote and 227 of the 351 seats in the DPR. After its first congress in Surabaya in 1973, Golkar then amalgamated its constituent groups into a single powerful state cadre with an instantly recognizable symbolic identity. Golkar's unrivaled access to state revenues combined with its distinctive organizational structure gave it a vast territorial reach at all levels of society and allowed it to dominate national and local legislatures and by extension the political life of the archipelago.

All of which allowed Suharto to operationalize his brand of patrimonial authority via a vast alliance of state officials, business interests, and community elites all the way down the chain to the village level. The executive, legislative, and judicial branches of the Indonesian state were little more than strands in a hegemonic web of corruption and graft. Suharto also knew enough about maintaining power to deny Golkar any major policy formation role or strong programmatic platform (Tomsa 2008). Suharto's mastery of divide-and-rule strategies to create internal factions kept Golkar from having strong leadership capable of challenging him. He used it more as a personal political vehicle, pressing it into service to mobilize public support and secure his reappointment as president. In fact, Golkar's status as a significant political party in the post-Suharto era rests less on its programmatic merits and more on its ability to take advantage of its hegemonic past.

\section{Conclusion}

In common with other transitions, the political euphoria that accompanied Indonesia's crumbling authoritarian regime raised expectations very high. Yet, as any observer of the Indonesian transition will tell you, it has been no easy ride since 1998 (Slater 2008: 208-213; Hadiz 2003: 591-611). The reason for this is that a transition is an entrance into a period of uncertainty. A period characterized by opportunity but also fraught with danger. What this article has established is that whilst regime downfall can be sudden, as it was in Indonesia, inherited constraints fade much less quickly. It also outlined tentatively a way of understanding Indonesia's democratic rearrangement vis-à-vis the legacies of the past.

The compromises necessary to ensure relative stability and a peaceful transition always disappoint in some 
respects. Despite a 'new' social contract, ambiguities abound. Patronage and old loyalties do persist if in a somewhat adapted form. This sort of modified continuation means the archipelago continues to experience widespread corruption, and officials especially the judiciary, remain open to bribery and graft (Hadiz 2004: 55-71). One need only look at the scandals surrounding the Indonesian Bank Restructuring Agency (IBRA), the State Logistics Agency (Bulog), or the Bank Indonesia Liquidity Assistance (BLBI) to get a sense of the scale of the problem. Having said this, the Supreme Audit Agency (BPK - Badan Pemeriksa Keuangan) and Corruption Eradication Commission (KPK - Komisi Pemberantasan Korupsi) has made some inroads against an endemic nexus of corruption and graft but it is without doubt a fraught and uneven struggle (Mulia 2008).

In many instances, community interests continue to remain marginalized and subordinate to the interests of local patrons of national parties. These situations are no more keenly felt than in provinces like Kalimantan and Papua Barat (West Papua). Yet, one of the encouraging effects of change is that there is now at least some acknowledgement of the regions. The 2004 election inaugurated the new Dewan Perwakilan Daerah (DPD Regional Representatives Council). It does constitute, in a narrow sense, a second chamber of elected representatives albeit with extremely limited powers. Taking a quick look at the fringes of national politics, there is also a number of minor opposition parties that represent labor interests. Partai Uni Demokrasi Indonesia (PUDI - Democratic Unity Party-Indonesia) Partai Buruh Nasional (PBN - National Labour Party) and Partai Pekerja Indonesia (PPI - The Indonesian Workers' Party), for instance, have some influence in and around Jakarta. But the parties just mentioned continue to lack broad appeal and show little signs of consolidating a political base capable of challenging for power (Johnson Tan 2006: 88-114).

Evidently, the establishment of multiparty democracy is a struggle against the patterns of the past. If one looks at the experience of Megawati Sukarnoputri's PDI-P, for instance, the challenge is patently obvious. Given her lineage, Megawati had wide appeal and played a key role in Indonesia's transition. She garnered mass support from rural, urban middle class, and working class constituencies. Yet, despite the wave of euphoria, her PDI-P party was organizationally weak and lacked an effective party structure capable of maintaining the popular support of 1999. On the other hand, Golkar, a discredited force in the 1999 election, retained its organizational reach to a large extent. This allowed it to claw back its vote in 2004. At the same time, its past imbued it with some distinctive and unmistakable weaknesses. Golkar's status as a significant political party in the post-Suharto era rests more on a hegemonic legacy than its programmatic or leadership merits. What Partai Demokrat's (PD Democratic Party) election victory in 2009 indicated was that Golkar's electoral success relied more on it taking advantage of an uneven political playing field than unequivocal institutional strength on its part.

Evidently, Indonesia's transformation, in common with other democratizations, has been anything but straightforward. The legacies of the past have made democratic re-arrangement vis-à-vis political power a complicated affair. Indonesia has had to face up to substantial challenges (and is still doing so) but, at the same time, it has managed to come through such a process and registered some quiet remarkable achievements over the 13 years since its initial transition (McBride 2004: 396-420). There may be ongoing policy ineffectiveness, judicial problems, institutional frictions and corruption issues but what is clear is that there has been substantive reform. The political system is now a functioning democracy with all its benefits and shortcomings. Success depended, in the Przeworskian (1991) sense, on relevant political forces working out how best to continue to submit their interests and values to the uncertain interplay of democratic institutions. Translating momentum for change into representational capacity with the ability to yield meaningful reform and improvements took time, commitment and vigilance. In fact, President Susilo Bambang Yudhoyono (SBY) may be ex-military but he is politically committed to the new democratic framework. And although high in the rhetoric stakes, he has at least sought to stabilize the economy, combat terrorism and make inroads against corruption. The institutional reforms of the post-Suharto political system have, albeit modestly, widened contestation that, in turn, created a more inclusive form of politics. No matter how constrained this potential is it has improved the system of governance.

From what has just been said about democratization in Indonesia, it should come as no real surprise that the kind of democracy (hybrid or otherwise) establishing itself does exhibit patrimonial tendencies (Webber 2006: 396-420). Political change after all occurs through time by way of contestation, destabilization, and reconstitution. There are no simple explanations, but rather matters of time and degree. This often means regressions, breakdowns, and unexpected patterns of transformation. We are not watching a linear trajectory to a predetermined endpoint but a renegotiation between a country's own history, culture, and identity. In fact, the process resists simple categorization as it oscillates between uncertainty, continuity, and change. Institutional outcomes will reflect disjunctive dynamics; constructing their own specificity in a nonlinear reiterative interplay between structure and agency. In short, ambiguity is to democratization as push is to shove.

If we are to accept this proposition then, reading multiple narratives into the context of a country's 
democratization is a useful step in unraveling ambiguity in post-authoritarian situations. For instance, by anatomizing and locating key aspects of Indonesia's past, in particular the New Order era, we can see it had certain material and ideational characteristics. They did not simply disappear in the aftermath of Suharto but actually constituted a significant part of the contingent terrain of Indonesia's unfolding democratization. The subsequent interplay between political decisions and embedded institutional rigidities and culturally informed practices shaped the democracy establishing itself. Indeed, ambiguity is the compromise we live with from the contestation and reinterpretation of these realities.

\section{References}

Anderson, B. (1991). Imagined Communities: reflections on the origin and spread of nationalism. London, Verso.

Anderson, B. (2001). Violence and the State in Suharto's Indonesia. Ithaca, NY, Southeast Asia Program Publications, Southeast Asia Program, Cornell University.

Bermeo, N. (1990). Rethinking Regime Change. Comparative Politics, 22(1), 359-377. http://dx.doi.org/10.2307/421966

Bertrand, J. (2004). Nationalism and Ethnic Conflict in Indonesia. Cambridge, Cambridge University Press.

Casper, G. (1995). Fragile Democracies: The Legacies of Authoritarian Rule. Pittsburgh, University of Pittsburgh Press.

Cribb, R. (ed.). (1990). The Indonesian killings of 1965-1966: Studies from Java and Bali. Melbourne: Centre of Southeast Asian Studies, Monash University.

Crouch, H. (1979). Patrimonialism and Military Rule in Indonesia. World Politics, 31(4), 578-587. http://dx.doi.org/10.2307/2009910

Diamond, L. (1997). Consolidating the Third Wave Democracies. Baltimore, Johns Hopkins University Press.

Diamond, L. (2002). Elections without Democracy. Journal of Democracy, 13(2), 21-36. http://dx.doi.org/10.1353/jod.2002.0025

Gramsci, A. (1971). Selections from the Prison Notebooks of Antonio Gramsci (Edited and translated by Q. Hoare, \& G. N. Smith). London/New York, International Publishers.

Hadiz, V, (2004). The Rise of Neo-Third Worldism? The Indonesian Trajectory and the Consolidation of Illiberal Democracy. Third World Quarterly, 25(1), 55-71. http://dx.doi.org/10.1080/0143659042000185336

Hadiz, V. (2003). Reorganizing Political Power in Indonesia: A Reconsideration of so-called Democratic Transitions. Pacific Review, 16(4), 591-611. http://dx.doi.org/10.1080/0951274032000132272

Johnson, T. P. (2006). Indonesia Seven Years after Soeharto: Party System Institutionalization in a New Democracy. Contemporary Southeast Asia, 28(1), 88-114. http://dx.doi.org/10.1355/CS28-1E

Karl, T. L. (1990). Dilemmas of Democratization in Latin America. Comparative Politics, 23(1), 1-23. http://dx.doi.org/10.2307/422302

Kim, Y. C., Liddle, R. W., \& Said, S. (2006, Summer). Political Leadership and Civilian Supremacy in Third Wave Democracies: Comparing South Korea and Indonesia. Pacific Affairs, 79(2), 247-268.

MacIntyre, A. (2000). Funny Money: Fiscal Policy, Rent Seeking and Economic Performance in Indonesia. In K. S. Jomo, \& M. Khan (Eds.), Rent Seeking in Southeast Asia. Cambridge, Cambridge University Press. http://dx.doi.org/10.1017/CBO9781139085052.007

Mamdani, M. (1996). Citizen and Subject: Contemporary Africa and the Legacy of Late Colonialism. Princeton, New Jersey, Princeton University Press.

McBride, E. (2004, December). Survey: Indonesia. The Economist, 9.

McCulloch, L. (2003). Trifungsi: The Role of the Indonesian Military in Business. In J. Brommelhorster, \& W. C. Paes (Eds.), The Military as Economic Actor - Soldiers in Business. London, MacMillan Palgrave.

McFaul, M. (2002). The Fourth Wave of Democracy and Dictatorship: Non-cooperative Transitions in the Post-Communist World. World Politics, 54(2), 212-244. http://dx.doi.org/10.1353/wp.2002.0004

McLeod, R. H. (2000). Soeharto's Indonesia: A better class of corruption. Agenda, 7(2).

Mulder, N. (1998). Mysticism in Java: Ideology in Indonesia. Amsterdam: Pepin. 
Mulia, E. (2008, March). Prevention crucial to combat corruption. The Jakarta Post, 6.

Ottoway, M. (2003). Democracy Challenged: The Rise of Semi-Authoritarianism. Washington D.C., Carnegie Foundation.

Przeworski, A. (1991). Democracy and the market: Political and economic reforms in Eastern Europe and Latin America. Cambridge: Cambridge University Press. http://dx.doi.org/10.1017/CBO9781139172493

Robison, R. (1986). Indonesia: The Rise of Capital. Canberra, Allen \& Unwin.

Siegel, J. T. (1997). Fetish, Recognition, Revolution. New Jersey: Princeton University Press.

Simanjuntak, M. (1994). Pandanang Negara Integralistik: Sumber, Unsur dan Riwayantnya dalam Persiapan UUD 1945 [The view of the Integralist State: Sources, Elements and its History in the Preparation of the 1945 Constitution]. Jakarta, Pustaka Utama Grafiti.

Singh, B. (2000). Civil-military relations in democratising Indonesia: Change amidst continuity. Armed Forces and Society, 26(4), 184-216.

Slater, D. (2006, Spring). The Ironies of Instability in Indonesia. Social Analysis, 50(1), 208-213. http://dx.doi.org/10.3167/015597706780886067

Tomsa, D. (2008). Party politics and democratization in Indonesia: Golkar in the post-Suharto era. London and New York: Routledge.

Webber, D. (2006). A consolidated patrimonial democracy? Democratization in post-Suharto Indonesia. Democratization, 13(3), 396-420. http://dx.doi.org/10.1080/13510340600579284

Zakaria, F. (1997, November-December). The Rise of Illiberal Democracy. Foreign Affairs, 76(6), 22-43. http://dx.doi.org/10.2307/20048274 